\title{
Degradation of Cibacron Red Dye using ZnO as a Catalyst Coated on the Surface of the Glass in the Photocatalytic Process
}

\author{
A. Sumartono ${ }^{1^{*}}$ and W. Andayani \\ Center for Application of Isotope and Radiation, National Nuclear Energy Agency \\ Jl. Cinere Pasar Jumat PO BOX 7002 JKSKL Jakarta 12070, Indonesia
}

\section{ARTICLE INFO}

Article history:

Received 20 November 2010

Received in Revised form 27 October 2011

Accepted 04 November 2011

Keywords:

Cibacron-red

Photocatalytic

$\mathrm{ZnO}$

\begin{abstract}
A B S T R A C T
Industrial discharges are the main causes of surface and groundwater contamination. Photocatalytic process is one of the methods that could be used to degrade organic compounds that released from industrial wastewater. Photocatalytic process of $10 \mathrm{ppm}$ cibacron red dye with irradiation of UV lamp and $\mathrm{ZnO}$ as a catalyst that coated on the surface of the glass the size of $8 \mathrm{~cm} \times 8 \mathrm{~cm} \times 0.4 \mathrm{~cm}$ have been studied. Experiments consisting of (i) variation of $\mathrm{ZnO}$ catalyst at temperature $200^{\circ} \mathrm{C}, 300^{\circ} \mathrm{C}, 400^{\circ} \mathrm{C}$, and $500^{\circ} \mathrm{C}$, and (ii) the efficiency achieved by the resulting $\mathrm{ZnO}$ obtained from the best variation in (i) as the UV-photocatalytic agent in degradation of cibacron red dye. The UV irradiation was done at interval time 0 ; $0.5 ; 1 ; 2 ; ; 4$; and 6 hours. Degradation could be achieved using $\mathrm{ZnO}$ catalyst at temperature $500^{\circ} \mathrm{C}$, the percentage degradation at $289 \mathrm{~nm}, 515 \mathrm{~nm}$, and $545 \mathrm{~nm}$ were $84.5 \pm 1.0 \%, 100 \%$ and $100 \%$, respectively.
\end{abstract}

\section{INTRODUCTION}

Textile industry is one of the largest water consumer, which produces wastewater containing highly colored effluents, therefore it would affect badly to both surface water and ground water. The presence of large quantities of colored wastewater blocked the penetration of light into the water and subsequently cause imbalance in their ecosystem. In general, the wastewater released from that industry is toxic and biological resistant and would pollute the environment, especially the water resources [1-2].

Decoloration of textile wastewater by conventional chemical and biological methods are difficult. Photocatalytic oxidation of organic substance from wastewater can be used as an alternative method [3]. The use of semiconductor can be activated by sunlight therefore reducing significantly the electric power requirement and operating cost, and the photocatalytic process is its mild operating conditions [4].

Photocatalytic oxidation using a semiconductor such as $\mathrm{TiO}_{2}, \mathrm{ZnO}, \mathrm{CdS}, \mathrm{WO}_{3}$ etc. as photocatalyst is one of the various advanced oxidation processes in recent years. They are very

\footnotetext{
* Corresponding author.

E-mail address: agustnsmt@batan.go.id
}

promising for effluent treatment mainly due to their high efficiency and simplicity of operation. Combination of UV light with catalysts such as $\mathrm{ZnO}$ is one of the advanced oxidation processes. $\mathrm{ZnO}$ appears to be suitable alternative to $\mathrm{TiO}_{2}$, since its photodegradation mechanism has been proven to be similar to $\mathrm{TiO}_{2}$ [5]. Zinc oxide with the wide bandgap of $3.32 \mathrm{eV}$ as compared to $\mathrm{TiO}_{2}$ $(3,0 \mathrm{eV})$ is an n-type semiconductor with many attractive features and is capable to generate hydroyl radicals [6].

The photocatalysis with $\mathrm{ZnO}$ represents a perspective field, because $\mathrm{ZnO}$ can be more efficient than of $\mathrm{TiO}_{2}$ in the photocatalytic degradation of some dyes in aqueous solution [7-8]. According to Yeber et al. [9], $\mathrm{ZnO}$ gained much attention in the degradation and complete mineralization of environmental pollutants. $\mathrm{ZnO}$ thin film have been found to decompose aqueous solutions of reactive dyes [7,10]. The preparation of film catalyst makes it possible and extend the industrial applications [11]. The sol-gel process and the utilization of dip coating technique are two of the versatile strategies to prepare thin films of particles. $\mathrm{ZnO}$ thin film are prepared by different techniques such as metal organic vapour deposition thermal evaporation, oxidation and anodization [12-17]. 
Recently it has been demonstrated that semi conductor materials mediated photocatalytic oxidation of organic compounds is a successful, convention alternative to conventional methods for the removal of organic pollutants from water. The greatest advantage of $\mathrm{ZnO}$ is that absorb large fraction of solar spectrum and more light quanta than $\mathrm{TiO}_{2}$ [18]. Photocatalysis process has been applied to solve various pollutant organic i.e humic acid, dyes, pentachlorophenol, and alkylbenzene sulfonat [19-21].

In this paper we demonstrated preparation of thin films of $\mathrm{ZnO}$ catalyst on glass substrates by the sol-gel method using dip coating technique. The films are prepared on glass substrate by dip coating several times and annealed at various temperature i.e $200^{\circ} \mathrm{C}, 300^{\circ} \mathrm{C}, 400^{\circ} \mathrm{C}$ and $500^{\circ} \mathrm{C}$. Further, studies on photocatalytic degradation of cibacron red dye in water using $\mathrm{ZnO}$ as catalyst in the various temperature and efficiency of the catalyst was observed. The objectives of the experiment is to find out the temperature influence of formation $\mathrm{ZnO}$ on the glass surface and the activity of $\mathrm{ZnO}$ as a catalyst to degrade cibacron red dye.

\section{EXPERIMENTAL METHODS}

\section{Reagents and equipments}

The reagents used in this study were $\mathrm{Zn}\left(\mathrm{CH}_{3} \mathrm{COO}\right)_{2}$, ethanol, methanol, and acetone. The dye used in this experiment was cibacron red and has a molecule structure in Fig. 1. Reaction vessel is a made of Pyrex glass (Fig. 2) with the size of $25 \mathrm{~cm} \times 11 \mathrm{~cm} \times 7 \mathrm{~cm}$. The reaction vessel is equipped with two 10 Watt UV-light-lamps, magnetic bar and two pieces of glass immobilised with $\mathrm{ZnO}$ with size of $8 \mathrm{~cm} \times 8 \mathrm{~cm} \times 0.4 \mathrm{~cm}$.

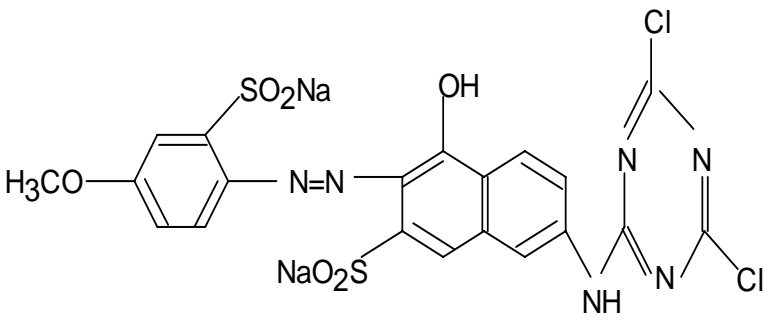

Fig. 1. Molecule structure of cibacron red.

\section{Experimental design}

\section{Preparation of ZnO catalyst}

Two pieces of glass plates with size of $8 \mathrm{~cm} \times$ $8 \mathrm{~cm} \times 0.4 \mathrm{~cm}$ were soaked in chromic acid, followed by rinsed with water, and acetone. The glass plates were dried in the oven at $110^{\circ} \mathrm{C}$ for 1 hour, after being cooled were weighed (Wo). The glass plates were coated with $10 \mathrm{ml}$ of $\mathrm{Zn}$ asetat at concentration of $1 \mathrm{mg} / \mathrm{mL}$ using metanol:etanol $(1: 4)$ as a solvent. The coating was done several times on the a surface of the glass. The glass plates were dried in a room temperature, after that were heated at various temperature i.e. $200^{\circ} \mathrm{C}, 300^{\circ} \mathrm{C}$, $400^{\circ} \mathrm{C}$ and $500^{\circ} \mathrm{C}$, respectively. After being cooled the glass were weighed $\left(\mathrm{W}_{1}\right)$. A $200 \mathrm{ml}$ of $10 \mathrm{ppm}$ cibacron red solutions were placed into the reaction vessel. Irradiation was done at interval time $0 ; 0.5$; 1; 2; 4; and 6 hours using variation of $\mathrm{ZnO}$ catalyst processed at different temperature. During irradiation, solution was stirred using magnetic bar. The whole irradiation was done at ambient condition. The change of the spectrum, were analyzed before and after irradiation. The absorption band was measured with a HP 8453 spectrophotometer UV-VIS. After irradiation the catalysts were dried and heated in the oven at $110^{\circ} \mathrm{C}$ for 1 hour and after cooled were weighed $\left(\mathrm{W}_{2}\right)$. From this step, the best condition of $\mathrm{ZnO}$ catalyst was used to do the next experiment.

\section{Reusage of ZnO catalyst}

The best condition of $\mathrm{ZnO}$ catalyst that come from the above experiment was heated in the oven at $110^{\circ} \mathrm{C}$ for 1 hour. After that,the $\mathrm{ZnO}$ catalyst was used again for photocatalytic process up to four times.

\section{Radiation of cibacron red at different treatment}

Radiation using the best $\mathrm{ZnO}$ catalyst was done at 6 hours at various treatment namely ie ; (a). $\mathrm{ZnO}+\mathrm{UV}$ light, (b). $\mathrm{ZnO}$, and (c). UV light. After the treatment, the change of the spectrum was measured using spectrophotometer UV-VIS.

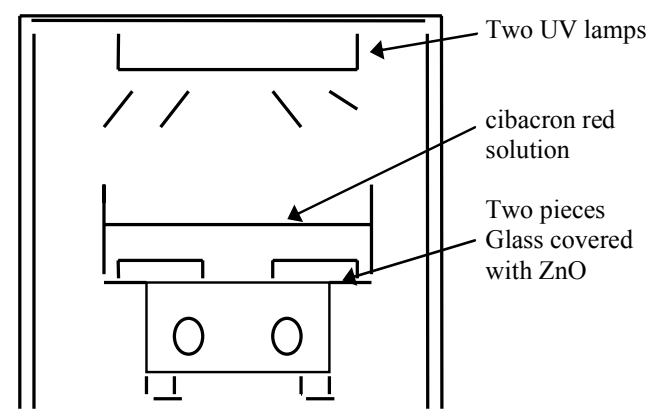

Fig. 2. Reactor for irradiated the sample. 


\section{RESULTS AND DISCUSSION}

\section{Preparation of $\mathrm{ZnO}$ catalyst at various temperature}

The weight of the catalyst (W1) at various temperature can be seen in Table 1. It could be seen that the weight of the catalyst on the surface of the glass at high temperature $\left(500^{\circ} \mathrm{C}\right)$ more heavy than that at low temperature. At low temperature, the formation of $\mathrm{ZnO}$ catalyst only a few, due to the unfinished formation of $\mathrm{ZnO}$. The formation of black thin layer on the surface of the glass indicated that formation of $\mathrm{ZnO}$ not complete yet. Therefore, the weight of the catalyst at low temperature less heavy. On the other hand the formation of white thin layer were formed on the surface of the glass when heated at high temperature $\left(500^{\circ} \mathrm{C}\right)$. The white thin layer on the surface of the glass indicated that formation of $\mathrm{ZnO}$ were completely formed. Heating process was done in order to form $\mathrm{ZnO}$ which can be attached on the surface of the glass. The higher the temperature the higher the amount of catalyst were formed.

Table 1. The weighed of catalyst on the surface of the glass at various temperature.

\begin{tabular}{cccc}
\hline \multirow{2}{*}{ Temperature } & \multicolumn{3}{c}{ Weighed of catalyst (mg) } \\
\cline { 2 - 4 } & $\begin{array}{c}\text { Glass } \\
\text { plate 1 }\end{array}$ & $\begin{array}{c}\text { Glass } \\
\text { plate } 2\end{array}$ & Total \\
\hline $200^{\circ} \mathrm{C}$ & 1.4 & 1.4 & 2.8 \\
$300^{\circ} \mathrm{C}$ & 1.6 & 1.7 & 3.3 \\
$400^{\circ} \mathrm{C}$ & 1.8 & 1.8 & 3.6 \\
$500^{\circ} \mathrm{C}$ & 2.0 & 2.0 & 4.0 \\
\hline
\end{tabular}

\section{The change of Cibacron Red spectra}

The cibacron red shows a clear absorption at 289, 515 and $545 \mathrm{~nm}$ in the UV and visible region as shown in Fig. 5. The former spectra can be assigned to their substituted aromatic rings, the second and the third are assigned to the conjugated system of the dye molecules. The absorbance of cibacron red after photocatalytic process using catalyst at various temperature i.e. $200^{\circ}, 300^{\circ}, 400^{\circ}$, and $500^{\circ} \mathrm{C}$, are shown in Fig. 5-8, respectively.

The absorption spectra of cibacron red at 289 , 515 , and $545 \mathrm{~nm}$ using catalyst at $200^{\circ} \mathrm{C}$ and $300^{\circ} \mathrm{C}$ decreased slowly after six hour irradiation. At $400^{\circ} \mathrm{C}$ the intensity spectra at 289,515 and 545 $\mathrm{nm}$ decreased markedly after six hour irradiation using catalyst from $0.278,0.170$ and 0.189 to 0.099 (64.4\%), 0.049 (72.5\%), and 0.051 (73.2\%), respectively. The absorbance values of cibacron red before and after six hours irradiation times are tabulated in Table 2. The percentage of absorbance decreasing after six hours irradiation are tabulated in Table 3. At $500^{\circ} \mathrm{C}$, the absorption of cibacron red at 289,515 , and $545 \mathrm{~nm}$ after six hours irradiation decreased markedly especially in the visible spectra, its disappeared almost completely, resulting the change of the colour from red into colourless. The changes would suggest destruction of the chromophoric group in the dye molecules. The absorbance in the uv spectra decreased from 0.278 to $0.043(84.5 \%)$, the decrease in intensity is due to the destruction of the aromatic rings in the dye molecules by the attack of $\mathrm{OH}$ radicals that formed from phorocatalytic process. The mechanisms degradation of the cibacron red dye is as follows [22] :

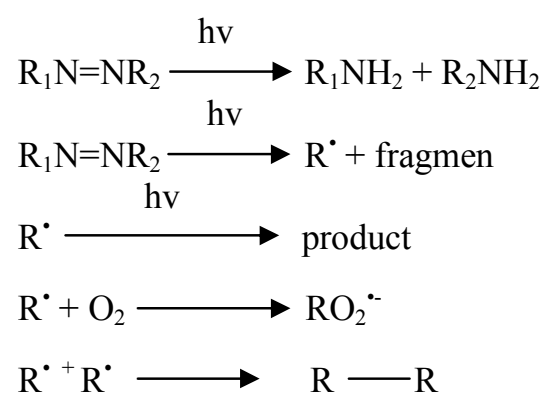

Intermediate product will absorbed foton and will formed product as shown in equation (3). When oxygen was bubbled into the solution, the intermediate product will oxidized into further compound as shown in equation (4). When there is no oxygen bubbled into the solution the organic radicals will combine into oligomer and polimer as shown in equation (5).

Cibacron red is an azo dye, it has a chemical bond $\mathrm{N}=\mathrm{N}$, degradation of the dye molecule is induced by the reaction with oxidative species (OH radicals) formed from photocatalytic process. In general, the mechanisms could be seen in Fig. 3 and 4. The $\mathrm{OH}$ radicals attack the azo linkage-bearing carbon (C-4) or hydroxy or aminesubstituted ring. The resulting $\mathrm{OH}$ adduct breaks down to produce fenildiazen and phenoxy radicals. Penildiazene is extremely unstable, $\mathrm{OH}$ or molecule oxygen can readily oxydize it by one electron to yeld a phenidiazene radical (Fig. 3) [23]. The latter intermediate is also unstable and cleaves homolytically to generate a phenyl radical and molecular nitrogen. The phenyl might abstract a hydrogen radical to produe benzene. The oxidation of benzene into carboxylic acid, such as oxalic acid through the formation of mucondialdehyde (Fig. 4) [24]. The formation of the carboxilic acid cause the decrease in the intensity both in UV and visible area in the spectrum (Fig. 8). 


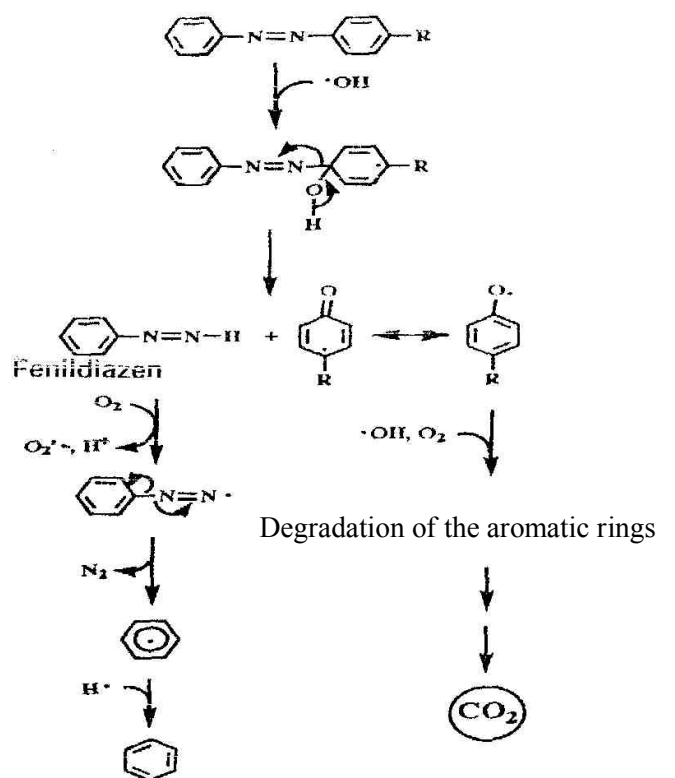

Fig. 3. The formation of benzene from azo dye [23].

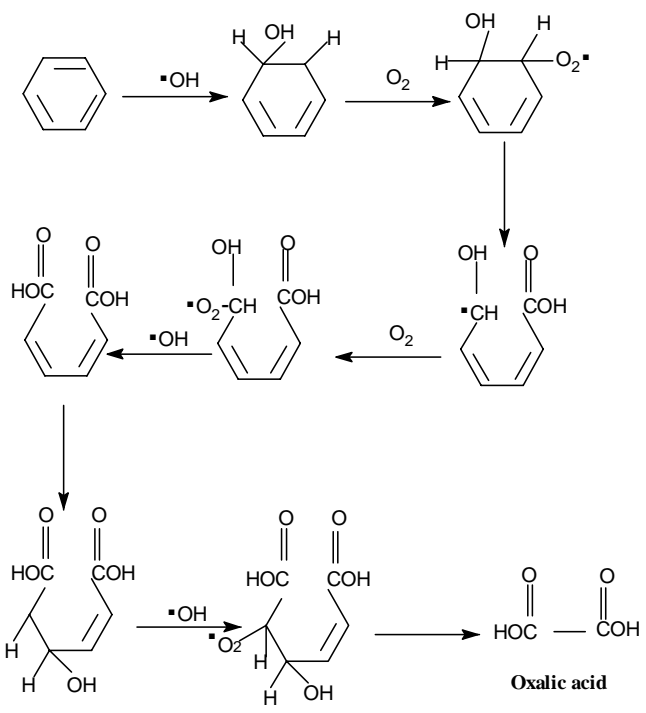

Sheme 2

Fig. 4 . The formation of oxalic acid from benzene [24].

Table 2. Absorbance values of cibacron red before and after six hours irradiation.

\begin{tabular}{cccc}
\hline \multirow{2}{*}{ Temperature } & \multicolumn{3}{c}{ Wave length $(\mathrm{nm})$} \\
\cline { 2 - 4 } & 289 & 515 & 545 \\
\hline 0 & 0.278 & 0.170 & 0.189 \\
$200^{\circ} \mathrm{C}$ & 0.188 & 0.108 & 0.115 \\
$300^{\circ} \mathrm{C}$ & 0.148 & 0.088 & 0.093 \\
$400^{\circ} \mathrm{C}$ & 0.099 & 0.049 & 0.051 \\
$500^{\circ} \mathrm{C}$ & 0.043 & -0.007 & -0.006 \\
\hline
\end{tabular}

Table 3. The percentage of absorbance decreasing after six hours irradiation.

\begin{tabular}{cccc}
\hline $\begin{array}{c}\text { ZnO catalyst } \\
\text { temperature } \\
\left({ }^{\circ} \mathrm{C}\right)\end{array}$ & $\lambda 289 \mathrm{~nm}$ & $\lambda 515 \mathrm{~nm}$ & $\lambda 545 \mathrm{~nm}$ \\
\hline 200 & $32.4 \pm 1.2 \%$ & $39.2 \pm 0.4 \%$ & $39.3 \pm 0.3 \%$ \\
300 & $46.7 \pm 0.7 \%$ & $50.5 \pm 1.1 \%$ & $50.7 \pm 0.7 \%$ \\
400 & $64.4 \pm 0.4 \%$ & $72.5 \pm 1.4 \%$ & $73.2 \pm 0.7 \%$ \\
500 & $84.5 \pm 1.0 \%$ & $103.8 \pm 1.1 \%$ & $102.9 \pm 0.7 \%$ \\
\hline
\end{tabular}

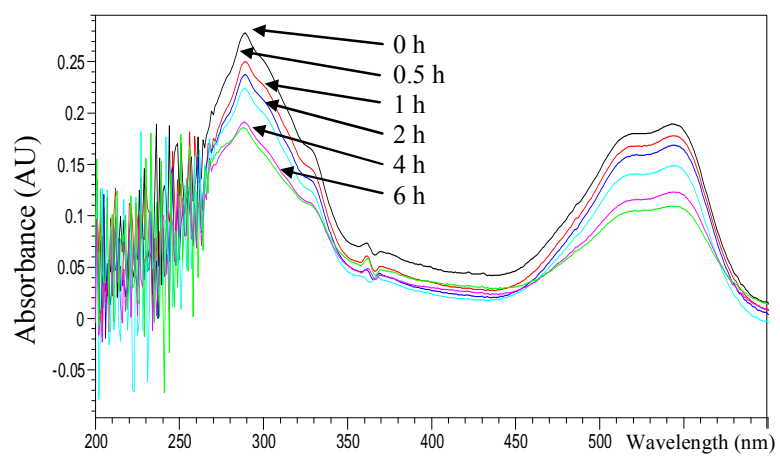

Fig. 5. Absorption spetra of cibacron red dye after photocatalytic proses using catalyst at $200^{\circ} \mathrm{C}(0 \mathrm{~h}=$ control; $0.5 \mathrm{~h} ; 1 \mathrm{~h} ; 2 ; 4 \mathrm{~h}$ and $6 \mathrm{~h}$ represent hours in radiation).

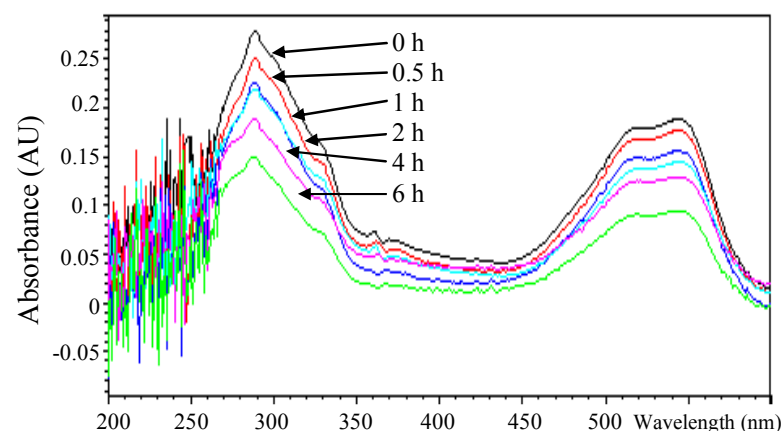

Fig. 6. Absorption spetra of cibacron red dye after photocatalytic proses using catalyst at $300^{\circ} \mathrm{C}(0 \mathrm{~h}=$ control; $0.5 \mathrm{~h} ; 1 \mathrm{~h} ; 2 \mathrm{~h} ; 4 \mathrm{~h}$ and $6 \mathrm{~h}$ represent hours in radiation).

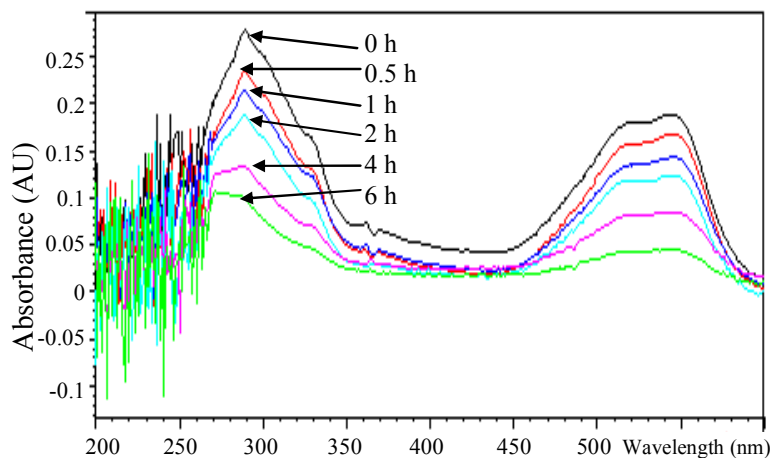

Fig. 7. Absorption spetra of cibacron red dye after photocatalytic proses using catalyst at $400^{\circ} \mathrm{C}(0 \mathrm{~h}=$ control; $0.5 \mathrm{~h} ; 1 \mathrm{~h} ; 2 \mathrm{~h} ; 4 \mathrm{~h}$ and $6 \mathrm{~h}$ represent hours in radiation). 


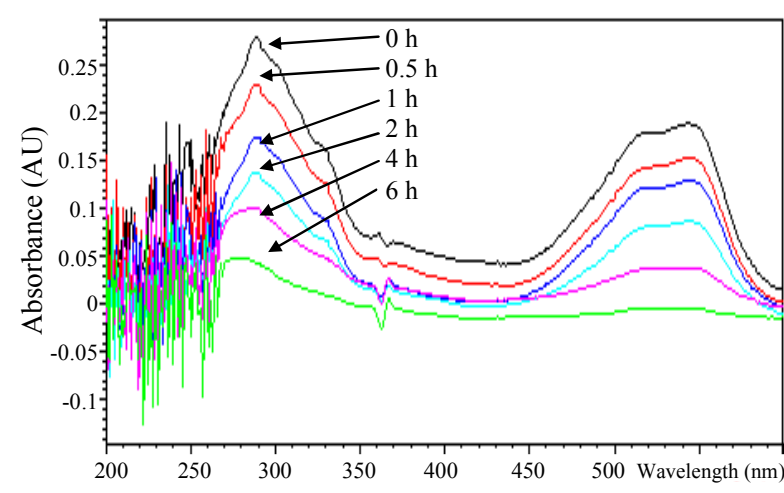

Fig. 8. Absorption spetra of cibacron red dye after photocatalytic proses using catalyst at $500^{\circ} \mathrm{C}(0 \mathrm{~h}=$ control; $0.5 \mathrm{~h} ; 1 \mathrm{~h} ; 2 \mathrm{~h} ; 4 \mathrm{~h}$ and $6 \mathrm{~h}$ represent hours in radiation).

\section{Reusage of $\mathrm{ZnO}$ catalyst}

It is noted that at temperature $500^{\circ} \mathrm{C} \mathrm{ZnO}$ catalyst shown a good results in degradation cibacron red solution. From this point of view, photocatalytic process using $\mathrm{ZnO}$ catalyst was conducted up to four times. The absorbance of cibacron red after using $\mathrm{ZnO}$ as a catalyst at first, second, third and fourth time are shown in Fig. 8-11, respectively. The percentage degradation of cibacron red after using catalyst several times were tabulated in Tabel 4. In the first usage the percentage degradation at 289,515 and $545 \mathrm{~nm}$ were $84.5 \pm 1.0 \%, 100 \%$ and $100 \%$, respectively. After second usage the percentage degradation were $64.1 \pm 2.0 \%, \quad 72.8 \pm 1.1 \%$ and $75.4 \pm 0.6 \% \quad$ at $289 \mathrm{~nm}, 515 \mathrm{~nm}$, and $545 \mathrm{~nm}$. At the third and fourth time of the reusage of the catalyst, the efficiency decreased gradually. From the results above, it is indicated that the usage of $\mathrm{ZnO}$ catalyst up to four times, will significantly decrease the activity of the catalyst. Another reason suggested that the formation of the catalyst in the surface of the glass decreased already.

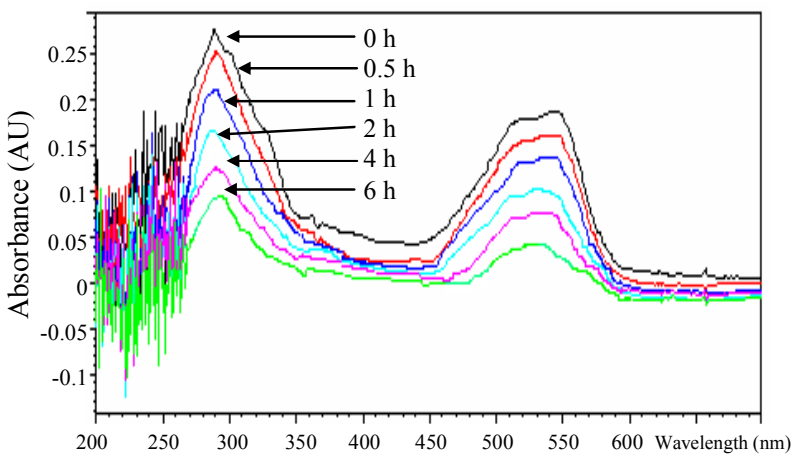

Fig. 9. Absorption spetra of cibacron red dye after photocatalytic proses using catalyst at $00^{\circ} \mathrm{C}$ for second time $(0 \mathrm{~h}=$ control; $0.5 \mathrm{~h} ; 1 \mathrm{~h} ; 2 \mathrm{~h} ; 4 \mathrm{~h}$ and $6 \mathrm{~h}$ represent hours in radiation).

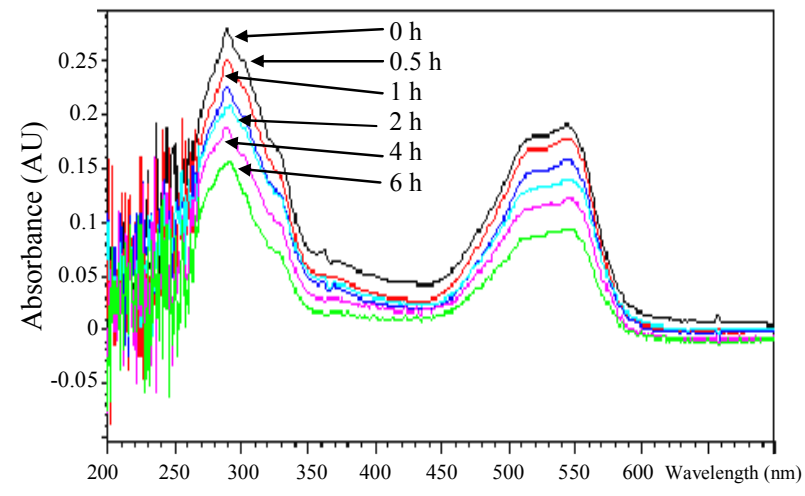

Fig. 10. Absorption spetra of cibacron red dye after photocatalytic proses using catalyst at $500^{\circ} \mathrm{C}$ after third time $(0 \mathrm{~h}=$ control; $0.5 \mathrm{~h} ; 1 \mathrm{~h} ; 2 \mathrm{~h} ; 4 \mathrm{~h}$ and $6 \mathrm{~h}$ represent hours in radiation).

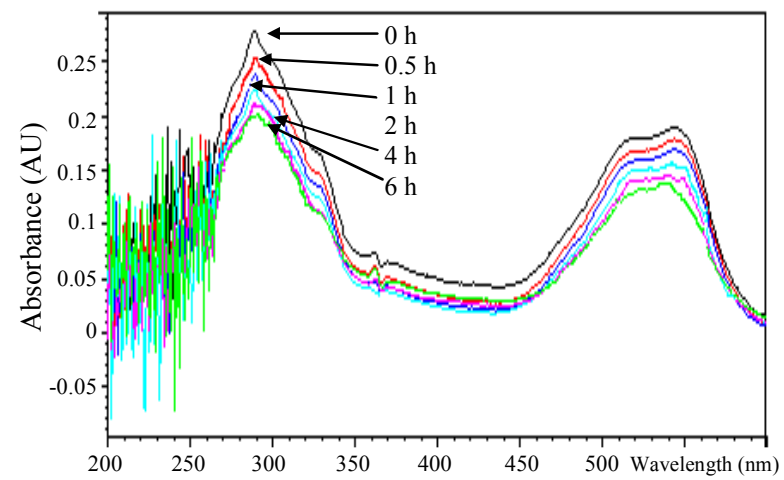

Fig. 11. Absorption spetra of cibacron red dye after photocatalytic proses using catalyst at $500^{\circ} \mathrm{C}$ after fourth time $(0 \mathrm{~h}=$ control; $0.5 \mathrm{~h} ; 1 \mathrm{~h} ; 2 \mathrm{~h} ; 4 \mathrm{~h}$ and $6 \mathrm{~h}$ represent hours in radiation).

Tabel. 4. The percentage degradation of cibacron red after reusage of $\mathrm{ZnO}$ catalyst

\begin{tabular}{cccc}
\hline \multirow{2}{*}{ Catalyst } & \multicolumn{3}{c}{ The percentage degradation } \\
\cline { 2 - 4 } & $\lambda 289 \mathrm{~nm}$ & $\lambda 515 \mathrm{~nm}$ & $\lambda 545 \mathrm{~nm}$ \\
\hline $500{ }^{\circ} \mathrm{C} 1^{\text {st }}$ & $84.5 \pm 1.0 \%$ & $100 \%$ & $100 \%$ \\
$500{ }^{\circ} \mathrm{C} 2^{\text {nd }}$ & $64.1 \pm 2.0 \%$ & $72.8 \pm 1.1 \%$ & $75.4 \pm 0.6 \%$ \\
$500{ }^{\circ} \mathrm{C} 3^{\text {rd }}$ & $44.2 \pm 0.09 \%$ & $46.8 \pm 12 \%$ & $48.4 \pm 0.6 \%$ \\
$500{ }^{\circ} \mathrm{C} 4^{\text {th }}$ & $21.2 \pm 0.1 \%$ & $23.3 \pm 0.3 \%$ & $27.7 \pm 0.4 \%$ \\
\hline
\end{tabular}

\section{Radiation of cibacron red at different treatment}

Radiation using $\mathrm{ZnO}$ catalyst $\left(500^{\circ} \mathrm{C}\right)$ was done at 6 hours at various treatment namely ie ; (a). $\mathrm{ZnO}+\mathrm{UV}$ lamp, (b). ZnO without UV lamp, and (c) . UV lamp. The intensity of the spectra at $289 \mathrm{~nm}$, $515 \mathrm{~nm}$ and $545 \mathrm{~nm}$ after six hours radiation with $\mathrm{ZnO}\left(500^{\circ} \mathrm{C}\right)+\mathrm{UV}$ lamp decreased markedly it can 
be seen from Fig. 8. The percentage degradation at $289 \mathrm{~nm}, 515 \mathrm{~nm}$ and $545 \mathrm{~nm}$ were $84.5 \pm 1.1 \%$; $100 \%$ and $100 \%$, respectively. The decrease in intensity is due to the destruction of the dye molecules by attack of $\mathrm{OH}$ radicals that formed from photocatalytic processes, the mechanisms is as follows (12):

$$
\begin{aligned}
& \mathrm{ZnO}+\mathrm{hv} \longrightarrow \mathrm{h}_{\mathrm{vb}+}+\mathrm{e}_{\mathrm{cb}-} \\
& \mathrm{h}_{\mathrm{vb}}{ }^{+}+\mathrm{H}_{2} \mathrm{O} \longrightarrow \mathrm{OH}^{\bullet} \\
& \mathrm{h}_{\mathrm{vb}}{ }^{+}+\mathrm{OH}^{-} \longrightarrow \mathrm{OH}^{\bullet} \\
& \mathrm{e}_{\mathrm{cb}}{ }^{-}+\mathrm{O}_{2} \longrightarrow \mathrm{O}_{2}{ }^{-} \\
& \mathrm{O}_{2}{ }^{\bullet}+\mathrm{H}+\longrightarrow \mathrm{HO}_{2} \bullet
\end{aligned}
$$

Figure 12 shows the treatment of cibacron red using $\mathrm{ZnO}$ catalyst $\left(500^{\circ} \mathrm{C}\right)$ without UV lamp, after six hours radiation, the intensity of the spectra at $289 \mathrm{~nm}, 515 \mathrm{~nm}$ and $545 \mathrm{~nm}$ remain constant. The percentage degradation at $289 \mathrm{~nm}, 515 \mathrm{~nm}$ and $545 \mathrm{~nm}$ were $5.4 \pm 1.4 \%, \quad 9.1 \pm 0.7 \%$, and $9.4 \pm 0.5 \%$, respectively. The same phenomena also occurred when cibacron red was irradiated using UV lamp without $\mathrm{ZnO}$ catalyst as seen from Fig. 13. The percentage degradation at $289 \mathrm{~nm}, 515 \mathrm{~nm}$ and $545 \mathrm{~nm}$ were $5.3 \pm 1.5 \%, \quad 9.6 \pm 0.02 \%$, and $9.8 \pm 0.06 \%$, respectively

It should be mention that radiation using UV lamp without $\mathrm{ZnO}$ catalyst, will cause no formation of $\mathrm{OH}$ radicals. The $\mathrm{OH}$ radicals are very powerful species for degradation of the dye molecules. Therefore, degradation of cibacron red occurred effectively using $\mathrm{ZnO}$ catalyst $\left(500^{\circ} \mathrm{C}\right)+\mathrm{UV}$ lamp.

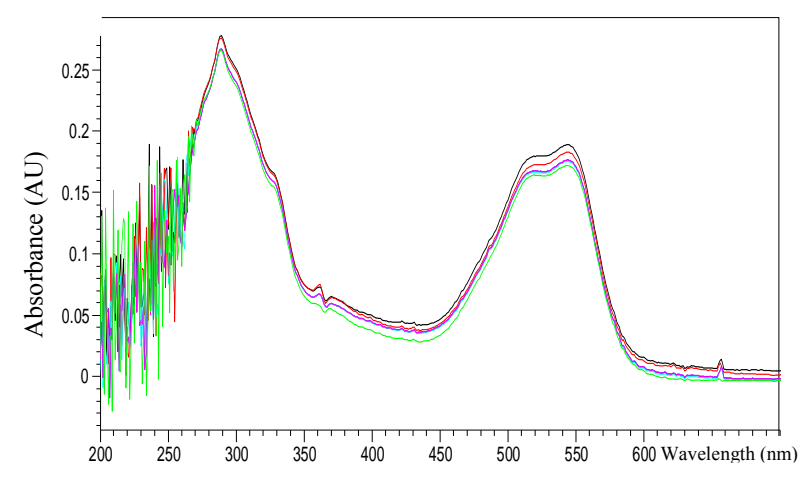

Fig. 12. Absorption spetra of cibacron red dye after treatment using $\mathrm{ZnO}$ catalyst $\left(500^{\circ} \mathrm{C}\right)$.

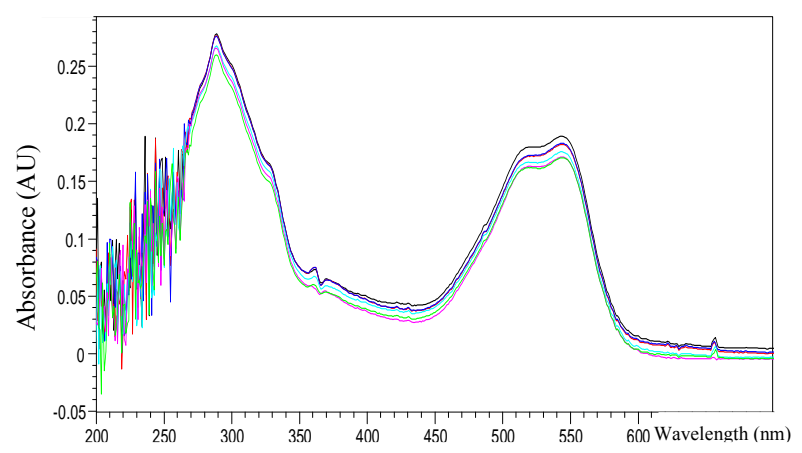

Fig. 13. Absorption spetra of cibacron red dye after treatment using UV lamp.

Table 5. shown the percentage degradation of cibacron red at various treatment namely (A). $\mathrm{ZnO}+\mathrm{UV}$ lamp, (B). $\mathrm{ZnO}$ and (C). UV lamp. From the result it is indicated that radiation using $\mathrm{ZnO}+\mathrm{UV}$ lamp resulting a good yield, due to the formation of $\mathrm{OH}$ radicals that can attack the structure of the dye molecules. The other two has no good resul because no formation of $\mathrm{OH}$ radicals.

Tabel 5. The percentage degradation of cibacron red irradiation at various treatment; (A). $\mathrm{ZnO}+\mathrm{UV}$ lamp, (B). $\mathrm{ZnO}$, and (C). UV lamp.

\begin{tabular}{cccc}
\hline Treatment & $\lambda 289 \mathrm{~nm}$ & $\lambda 515 \mathrm{~nm}$ & $\lambda 545 \mathrm{~nm}$ \\
\hline A & $84.5 \pm 1.0 \%$ & $100 \%$ & $100 \%$ \\
B & $5.4 \pm 1.4 \%$ & $9.1 \pm 0.7 \%$ & $9.4 \pm 0.5 \%$ \\
C & $5.3 \pm 1.5 \%$ & $9.6 \pm 0.02 \%$ & $9.8 \pm 0.06 \%$ \\
\hline
\end{tabular}

\section{CONCLUSION}

The use of $\mathrm{ZnO}$ as a catalyst coated on the surface of the glass after heated at temperature $500^{\circ} \mathrm{C}$ could be used to degrade cibacron red dye in the photocatalytic process. The colour of the dye at $10 \mathrm{ppm}$ concentration were changed after six hours radiation from red into clear colour. The degree of degradation in the 289,515 and $545 \mathrm{~nm}$ was achieved to be $84.5 \pm 1 \% \%, 100 \%$ and $100 \%$, respectively.

\section{REFERENCES}

1. W. Somasiri, R. Wenquan, X. Li and J. Chen., Electron. J. Environ. Agric. Food Chem. 5 (2006) 1.

2. N. Getoff, Rad. Phys. Chem. (2002) 437.

3. D.F. Ollis, E. Pelizzetti and N. Serpone, Environ. Sci. Tech. 25 (1991) 1522. 
4. D.Y. Goswami, Advance Solar Energy 10 (1995) 165.

5. L.B. Reutergardh and M. Langsphasuk, Chemosphere 35 (1997) 585.

6. M.R. Hoffmann, S.T. Martin, W. Choi and D.W. Bahnemann, Chem. Rev. 95 (1995) 69.

7. G. Cak, F. Wypych, S.G. Moraes, N. Duran, N. Nagata and P.P. Zamora, Chemosphere 40 (2000) 433.

8. B. Dindar and S. Icli, J. Photochem. Photobiol. A 140 (2001) 261.

9. M.C. Yeber, J. Rodriguez, J. Freer, N. Duran and H.D. Mansilla, Chemosphere 41 (2000) 1193.

10. C. Lizama, J. Ferrer, J. Baeza and H.D. Mansilla, Catal. Today 76 (2002) 35.

11. K. Iketani, R.D. Sun, M. Toki, K. Hirota and O. Yamaguchi, Mater. Sci. Eng. B $\mathbf{1 0 8}$ (2004) 187.

12. J.L. Yang, S.J. An, W.I. Park, G.Y. Yi and W. Choi, Adv. Mater. 16 (2004) 1661.

13. B. Pal and M. Sharon, Mater. Chem. Phys. 76 (2002) 82.

14. F. Peng, S.H. Chen, L. Zhang, H.J. Huang and Z.Y. Xie, Acta Phys. Chem. Sin. 21 (2005) 944.
15. Y. Yamaguchi, M. Yamazaki, S. Yoshihara and T. Shirakashi, J. Electroanal. Chem. (1998) 442.

16. I. Alivov Ya, A.V. Chernykh, M.V. Chukichev and R.Y. Korotkov, Thin Solid Films 473 (2005) 241.

17. O.A. Fouad, A.A. Ismail, Z.I. Zaki and R.M. Mohamed, Appl. Catal. B 62 (2006) 144.

18. A.L. Linsebigler, L.U. Guangquan and J.T. Yates, Chem. Rev. 95 (1995) 735.

19. W. Andayani, A. Sumartono and M. Lindu, Semiloka Nasional-Himpunan Kimia Indonesia, Jakarta (2003).

20. A. Sumartono, W. Andayani, N. Hidayati and N.D. Utami, Prosiding Temu Jaringan Kerjasama Kimia Indonesia (2003).

21. W. Andayani, A. Sumartono and M. Lindu, Prosiding Temu Ilmiah Jaringan Kerjasama Kimia Indonesia (2002).

22. X. Feng, Zhu and H. Han, Water SA. 32 (2006) 43.

23. J.T. Spadaro, Isabelle and V.H. Renganathan, Env. Sci. Technol. 28 (1994)1389.

24. M.G. Nickelsen, W.J. Cooper, C.D. Kurucz and T.D. Waite, Environ. Sci. Technol. 26 (1992) 144. 